\begin{tabular}{|l|l|}
\hline $\begin{array}{l}\text { Postprint } \\
\text { Version }\end{array}$ & 1.0 \\
\hline Journal website & http://onlinelibrary.wiley.com/doi/10.1111/ina.12064/abstract \\
\hline Pubmed link & $\underline{\text { http://www.ncbi.nlm.nih.gov/pubmed/23927557 }}$ \\
\hline DOI & 10.1111/ina.12064
\end{tabular}

This is a NIVEL certified Post Print, more info at http://www.nivel.eu

\title{
Endotoxin levels in settled airborne dust in European schools: the HITEA school study
}

\author{
J. H. JACOBS ${ }^{1,+, *}$, E. J. M. KROP ${ }^{1, \dagger}$, A. BorRAS-SANTOS ${ }^{2,3,4}$, J.-P. ZOCK ${ }^{2,3,4}$, M. TAUBEL ${ }^{5}$, A. \\ HYVARINNEN $^{5}$, J. PEKKANEN ${ }^{5,6}$, G. DOEKES ${ }^{1}$, D. J. J. HEEDERIK ${ }^{1}$ AND ON BEHALF OF THE \\ HITEA SCHOOLS STUDY CONSORTIUM
}

\section{ABstract}

In door exposure to microbial agents is known to influence respiratory health. Besides home exposure, exposure in schools can affect respiratory health. In this study, we measured endotoxin in settled dust in primary schools in three European countries from three different geographical regions with different climates. Our aim was to characterize endotoxin levels in primary schools and evaluate associations with potential determinants. Endotoxin levels were repeatedly assessed in 23 schools in Spain $(n=7)$, the Netherlands $(n=10)$, and Finland ( $n=6)$ using electrostatic dustfall collectors. In total, 645 measurements were taken in 237 classrooms. Endotoxin levels differed significantly between countries; Dutch schools had the highest levels, while Finnish schools showed the lowest levels. In each country, differences in endotoxin levels were observed between schools and over the sampling periods. Estimates improved after adjustment for sampling period. Factors affecting endotoxin levels in a school differed per country. In general, endotoxin levels were higher in lower grades and in classrooms with higher occupancy. School endotoxin levels may contribute significantly to total endotoxin exposure in children and teachers. As the correlation between the repeated measurements is reasonable, single endotoxin measurements form a reasonable basis for estimating annual endotoxin levels in schools.

\section{PRACTICAL IMPLICATIONS}

Endotoxin levels in schools can potentially be high, higher than levels that have been measured in the home environment. Elevated endotoxin levels have to be considered as a potential health relevant exposure in schools. Elevated levels seemed associated with the activity of the children and crowding. 


\section{INTRODUCTION}

Indoor Air Quality is essential for human health as a substantial proportion of time is spent indoors. Especially children are susceptible to potentially harmful pollutants in the indoor environment as their lungs are not fully developed. Associations between poor Indoor Air Quality and respiratory symptoms have often been reported (World Health Organization, 2009). Endotoxin, a component of the outer layer of Gramnegative bacterial cell walls, is ubiquitous in many indoor environments and can influence respiratory health. Most studies in which indoor endotoxin was assessed for children involved the home environment. Two recent studies reported higher endotoxin levels in schools (Jacobs et al., 2013; Sheehan et al., 2012) in comparison with the home environment. In one study, school endotoxin levels were associated with higher respiratory symptom rates (Jacobs et al., 2013). This finding is in agreement with studies reporting that increased personal endotoxin exposure is associated with an increased occurrence of asthma symptoms and a decrease in lung function (Rabinovitch et al., 2005; Rennie et al., 2008). In contrast, endotoxin exposure during childhood may also have a protective effect on the development of allergic sensitization (Braun-Fahrlander et al., 2002; Douwes et al., 2004; Gehring et al., 2002).

Few studies have explored endotoxin levels in schools and their relations with potential determinants (Foarde and Berry, 2004; Rabinovitch et al., 2005; Rullo et al., 2002; Sheehan et al., 2012). The lack of attention to this topic is surprising given that children spend a considerable proportion of their time at school. Moreover, schools are places with high occupant density and high level of activity. Pollutants bound to soil particles may be tracked in and lead to airborne exposure after resuspension. Prior studies that aimed to describe endotoxin levels in elementary schools involve convenience samples from a few schools or usually only a few measurements per school were involved. Consequently, it is unclear whether these findings reflect the situation in most schools (Foarde and Berry, 2004; Rabinovitch et al., 2005; Rullo et al., 2002). A recent study explored school endotoxin levels more extensively at 117 locations in 12 schools (Sheehan et al., 2012). Inner-city children encountered higher concentrations of endotoxin in classrooms than in their bedrooms.

So endotoxin levels in schools are likely to contribute to the total burden of endotoxin exposure, but variability and determinants of endotoxin levels in schools are not well-characterized. Therefore, the aims of the present study were to evaluate the indoor levels of endotoxin in settled dust in primary schools, to explore differences between schools, classrooms, and countries, and to study potential determinants of indoor endotoxin levels. In 23 primary schools in three different geographical regions in Europe, we performed repeated dust sampling from various locations in each school. This study is part of a larger project in which effects of agents associated with excess moisture, such as microbes and their products, on human health in both homes and schools in Europe are studied. The so-called electrostatic dustfall collector (EDC) has been used, which can be applied in largescale surveys at low costs. In addition, endotoxin from settled dust sampled with the EDC showed a good correlation with both actively sampled PM10 airborne particles 
Jacobs, J.H., Krop, E.J.M., Borras-Santos, A., Zock, J.P., Täubel, M., Hyvärinen, A., Pekkanen, J., Doekes, G., Heederik, D.J.J. Endotoxin levels in settled airborne dust in European schools: the HITEA school study. Indoor Air: 2014, 24(2), 148-157

and floor dust (Noss et al., 2008). Part of the exposure data have been published nivel before; however, the prior work did not explore for associations of measured levels with potential determinants (Jacobs et al., 2013).

\section{MATERIALS AND METHODS}

\section{Selection of the schools}

As part of the HITEA school study, primary schools in three European countries in different geographical areas were identified to represent three different climatic regions. The participating schools were selected for this study as described elsewhere (Borràs-Santos et al., 2013; Haverinen-Shaughnessy et al., 2012). In short, the aim was to enroll a minimum of 48 schools including both moisture damaged ( $n \geq 24)$ and control schools $(n \geq 24)$. In all three countries (Spain, the Netherlands and Finland), in total 738 schools were contacted and asked to complete a questionnaire by regular mail, phone interview, or Internet, focusing on current and past dampness, moisture damage, and mold problems and collecting extensive general information on the school buildings. The schools were located in a convenient geographical proximity to the conducting study center, that is, in the region proximate to the cities of Barcelona, Utrecht, and Kuopio for, respectively, Spain, the Netherlands, and Finland. Eventually, 53 schools were selected for further building inspections. Only schools with complete questionnaire information, more than 200 pupils, and which had not planned major repairs or renovations in the next 2 years were included. The school building inspections were performed by centrally trained research personnel and included walk-throughs accompanied by a school representative, utilizing predesigned checklists, and simple indoor climate measurements (HaverinenShaughnessy et al., 2012). Twenty-three schools were included for detailed exposure assessment and were selected based on the inspection data, representing the strongest cases and controls in each country. This determination was based on the presence of dampness, moisture or mold in the classrooms and their extent and observed severity. Schools were classified as affected by moisture damage or dampness (index schools) or as unaffected (reference schools) as previously described (Haverinen-Shaughnessy et al., 2005). In Spain, seven schools (five index and two reference) participated, in the Netherlands 10 schools (five index and five reference), and in Finland six schools (four index and two reference).

\section{Sampling of settled airborne dust and additional exposure information}

Measurements were taken for 8 weeks with the EDC (Jacobs et al., 2013; Noss et al., 2008), which passively collects settled airborne dust onto electrostatic cloths (Zeeman, Utrecht, the Netherlands) and is easily applicable in large-scale studies. Each school was sampled repeatedly in three periods: during winter/spring of 2009 (EA1), during spring/summer of 2009 (EA2), and during winter/spring of 2010 (EA3). The start date of the 8-week sampling surveys was not exactly the same in each country and school but differed slightly due to vacation periods and logistic reasons (Table 1). During each sampling period, the same locations were sampled whenever possible. Sampled room types included full-time used classrooms (attended by children from age 4 to 12), part-time used classrooms, teachers' 
lounges, hallways, libraries, dining rooms, gyms, and a group of other rooms such as offices. Showers and toilets were only included in the first sampling period.

\section{[TABLE 1]}

Electrostatic dustfall collectors were placed on the top of cupboards, bookshelves, or manufactured EDC-holders at on average 15 locations per school per sampling period. Collectors were placed away from windows, doors, ventilation ducts, and heating units. The minimum sampling height was $150 \mathrm{~cm}$ from the floor to collect settled airborne dust rather than tracked-in soil. After 8 weeks of sampling, samplers were closed and transported to the local study center where cloths were stored at $-20^{\circ} \mathrm{C}$. For analyses, samples were shipped on dry ice to the laboratory of IRAS, Utrecht, the Netherlands.

For each sample, information on sampling location and irregularities during sampling was recorded. Samples were excluded from analysis if the EDC had been moved or had been covered during the sampling period.

Information on cleaning policy (frequency and use of cleaning products) and building characteristics were derived from checklists obtained during the initial building inspections and from a short questionnaire completed by the cleaning manager or school representative during the last sampling period, all on building level. Indoor air temperature, relative humidity, and $\mathrm{CO}_{2}$ levels were measured with the Q-Trak Indoor Air Quality Meter (Model 7565, TSI Incorporated, St. Paul, MN, USA) every 5 min during 1 week from one classroom per school. Classrooms selected for these measurements were occupied by children aged 10-11 years, and measurements were taken in the 1st and 3rd sampling period.

\section{Extraction}

One cloth per EDC sampler was extracted as described earlier (Noss et al., 2008). For endotoxin analysis, cloths were incubated for $60 \mathrm{~min}$ in $20 \mathrm{ml}$ pyrogen-free water (B. Braun NPBI, Oss, the Netherlands) in an end-over-end roller. After centrifugation for $15 \mathrm{~min}$ at $1000 \mathrm{~g}$, the supernatant was stored in $200-\mu \mathrm{l}$ aliquots in pyrogen-free glass tubes at $-20^{\circ} \mathrm{C}$ until analysis.

\section{Endotoxin analysis}

Extracts were tested for endotoxin content with the Limulus amoebocyte lysate (LAL) assay (Lonza Group, Basel, Switzerland) according to the manufacturer's protocol. Samples were tested in 1:25 and/or 1:50 dilutions, and the resulting endotoxin units (EU) per ml values were converted into $\mathrm{EU} / \mathrm{m}^{2}$ (Noss et al., 2008). The limit of detection (LOD) of the assay was assessed at $300 \mathrm{EU} / \mathrm{m}^{2}$. Of the 1043 samples tested, five had levels below the LOD and were assigned a value 2/3 of the LOD (200 EU/m ${ }^{2}$; Noss et al., 2010). For $10 \%$ of the extracts, a second aliquot was measured on a separate occasion, and the mean coefficient of variation (\% CV) for duplicate samples in this series was $14 \%$. 


\section{Statistical analysis}

Statistical analyses were performed using SAS version 9.2 (SAS Institute, Cary, NC, USA). The MEANS procedure was used to calculate average levels per country and measuring period. Endotoxin concentrations were log-normally distributed, and analyses were performed using log10-transformed values. Because school occupants (pupils and teachers) spend most of their time in classrooms, only classroom levels were modeled. A 'zone' was defined as a cluster of classrooms that was situated in the same area or wing of a school and was classified by the person responsible for the fieldwork in that country.

Mixed-effect models (MIXED procedure) were used to explore the variability in endotoxin levels as well as to study associations between endotoxin levels and covariates, adjusting for possible correlation between measurements within countries, schools and measurements on the same location over time. Covariates considered were as follows: occupancy (i.e., number of children per classroom), sampling period, average indoor temperature and relative humidity during the sampling period, school grade (as indicator of age and activity of the children), cleaning practices, and information of the school buildings collected during the building inspections. School was included as a random effect. All covariates with a $P$-value lower than 0.20 in univariate analyses were selected for further analysis by backwards regression analysis. Next, the least significant independent variable was eliminated until the model included only variables with a $P$-value lower than 0.05 . Country, school, school building, zone, and classroom were considered as random effects to explore how the range in endotoxin levels was explained by these variables. To compare variability in endotoxin levels within and between the different categories, the variance ratio $\lambda$ was estimated as the ratio of the withincategory variance component and the between-category variance component $\left(\sigma_{\text {within }}{ }^{2} / \sigma_{\text {between }}{ }^{2}\right)$. The intraclass correlation coefficient $(\rho)$, calculated as the ratio of the between-school variance and the sum of both variance components, was also presented. Variance components were expressed as geometric standard deviations (GSD) to facilitate interpretation.

\section{RESULTS}

Average endotoxin levels differed greatly among countries (Table 1). The highest levels were measured in the Netherlands and were a factor 8-28 higher than in Finland, where the lowest levels were measured. There was a 4- to 18-fold difference between endotoxin levels in Spain and Finland. In Finland, outdoor temperatures and indoor relative humidity were considerably lower during all three sampling periods compared with the Netherlands and Spain. The data also exhibited considerable temporal variation in endotoxin levels. Levels were significantly higher in Finland during spring measurements compared with both winter periods $(P<0.001)$. In Spain, endotoxin levels were significantly lower $(P<0.05)$ in spring/summer than in winter. In the Netherlands, average endotoxin levels in both sampling periods in 2009 differed significantly $(P<0.05)$ from winter/spring 2010. In general, endotoxin levels were higher (6-85\% difference) in schools with water damage issues (index 
schools) as compared to reference schools, but this difference only reached borderline statistical significance in Dutch schools $(P=0.09)$.

Endotoxin levels for the different room types are shown per country for the first sampling period in Figure 1. In Spain and the Netherlands, endotoxin levels were higher in full-time classrooms compared with other location types $(P \leq 0.01$; data not shown). Endotoxin levels were also high in hallways and bathrooms. In Finland, endotoxin levels were highest in hallways, but levels were also high in full-time classrooms. Also locations such as libraries, showers, and gyms had high endotoxin levels; however, these locations were not present in every school.

\section{[FIGURE 1]}

Differences in endotoxin levels were mainly explained by differences between countries (83\%; Table 2) and, to a much lesser extent, by sampling period (12\%). Country-specific analyses revealed distinctly different patterns in variability for each country. In Spain, differences between schools (43\%) and between sampling periods (51\%) were predominant. This was also observed in the Netherlands, but here also significant differences were found in endotoxin levels between moisture categories (13\%) and buildings within the same school (11\%). In Finland, levels were low and variation in endotoxin was, in absolute terms, small, as shown by the low GSDs (see also Table 3). Differences between the different periods were relatively high and explained the major part of the total variance (86\%). Differences between schools were smallest in Finland (7\%).

\section{[TABLE 2][TABLE 3]}

In Spain, the between-school endotoxin variability (GSD = 1.21) was comparable with the within-school variability (GSD $=1.23$; Table 3 ), resulting in an intraclass correlation $(\rho)$ of 0.46 . This ratio hardly changed when measurements were grouped by building, zone, or classroom, indicating that any of these classifications produce very similar estimates of endotoxin level in settled dust. Comparable results were found for the Netherlands, although the variability between classrooms was somewhat larger than the temporal variability within classroom $(\mathrm{GSD}=1.21$ vs. 1.17, $\rho=0.62$ ). In Finland, differences in endotoxin levels between sampling periods were large, resulting in a relatively large temporal variability in endotoxin levels within classrooms over time and little variability between schools, buildings, school zones or classrooms. Within-group GSDs were large (1.44-1.48) compared with between-group GSDs (1.07-1.17), thus resulting in strongly overlapping endotoxinlevel distributions and little contrast. After adjustment for sampling period, the intraclass correlations for Spain and the Netherlands improved slightly (to 0.51 and 0.65 for, respectively, Spain and the Netherlands). In Finland, however, differences in endotoxin levels within classrooms became smaller when adjusting for sampling period $(\rho=0.51)$ and the between- and within-classroom GSDs became comparable with Spain and the Netherlands.

Determinants affecting endotoxin levels in a school differed by country. A selection of these determinants is presented in Table 4. The full list can be found in Table S1 
in the online supporting information. Overall, higher classroom occupancy was positively and significantly associated with endotoxin levels, while significantly lower endotoxin levels were found in classrooms that were occupied by children of a higher grade (Table 4). Cleaning tended to be associated with lower endotoxin levels, but only in Finland and the Netherlands. In Finland, sweeping was associated with higher endotoxin levels, probably caused by resuspension of dust. School buildings that were built more recently had lower endotoxin levels, while major water intrusion during the past 5 years was associated with higher endotoxin levels. In Spain, increased endotoxin levels were found in schools with higher indoor relative humidity and temperature. Other factors, such as floor material in classrooms, the condition of the building, and complaints of dampness and mold and odor, were not consistently associated with endotoxin levels (Table 4 and Table S1). In the stepwise backward regression analysis, sampling period and indoor relative humidity remained significant for Spain; in the Netherlands, sampling period, grade, the presence of stuffed toys, and the roof condition were significantly associated with endotoxin levels; and, in Finland, the sampling period, grade, and the sweeping frequency remained in the model. These covariates explained, after inclusion in the mixed-effect model, $8 \%, 30 \%$, and $60 \%$ of the total endotoxin variability within schools in Spain, the Netherlands, and Finland, respectively (Table S2).

\section{[TABLE 4]}

\section{DISCUSSION}

In the present study, we analyzed endotoxin levels in school buildings from an extensive survey in a large number of schools in three geographical zones of Europe. Repeated endotoxin measurements over a year sampled during three occasions were available from 23 schools in three countries. This density of data contrasts with earlier studies, where data are typically available only from a very limited number of schools or locations within schools (Foarde and Berry, 2004; Rabinovitch et al., 2005; Rullo et al., 2002). Average levels were highest in the Netherlands, approximately 20-60\% lower in Spain and considerably lower (>85-90\%) in Finland. In each country, major sources of endotoxin variability were the school and the sampling period. We found smaller differences in endotoxin levels between different buildings, zones, or classrooms within the school. Factors affecting endotoxin levels in a school differed per country.

Endotoxin levels in schools are likely to contribute considerably to the total burden of endotoxin exposure in children as indicated recently by two studies. A study in the Boston area of the USA found higher endotoxin levels in schools than in bedrooms of asthmatic children (Sheehan et al., 2012). Similar findings were obtained in the Netherlands: Classroom endotoxin levels were up to four times higher than home endotoxin levels in both asthmatic and non-asthmatic children (Jacobs et al., 2013). We also found borderline significant associations between school endotoxin levels and the occurrence of asthma symptoms. Endotoxin levels in this study, in particular in the Spanish and Dutch schools, were relatively higher compared with Dutch and Danish non-farming homes (Frankel et al., 2012; Madsen et al., 2012; Noss et al., 2008) and compared with Dutch animal clinics (Samadi et al., 2010). This outcome 
Jacobs, J.H., Krop, E.J.M., Borras-Santos, A., Zock, J.P., Täubel, M., Hyvärinen, A., Pekkanen, J., Doekes, G., Heederik, D.J.J. Endotoxin levels in settled airborne dust in European schools: the HITEA school study. Indoor Air: 2014, 24(2), 148-157

underlines the importance of characterizing endotoxin levels and exposure estimation in schools in studies on respiratory health effects in children.

Also, some other studies have measured endotoxin in schools, but with other sampling approaches. Levels in schools were in general relatively high (Foarde and Berry, 2004; Fromme et al., 2008; Rullo et al., 2002; Zhao et al., 2008) compared with levels found in studies in homes (Gehring et al., 2008; Tischer et al., 2011). However, comparisons are limited as measurements are taken in different populations and media (air, floor, or mattress dust) and are expressed in different units (EU per $\mathrm{m}^{3}, \mathrm{EU} / \mathrm{m}^{2}$ or EU/mg dust). In most studies, endotoxin levels are derived from floor dust. Although the use of floor dust samples is generally accepted, studies in homes found that levels differed extensively between settled floor dust and airborne particles collected with active sampling methods (Noss et al., 2008; Park et al., 2000). This outcome indicates that floor dust may not represent the inhaled endotoxin fraction as measured in airborne particulate matter. In addition, a major part of the collected floor dust in schools consists of large and heavy particles such as sand and breadcrumbs, which will not become airborne. Consequently, the use of endotoxin expressed as EU/mg may be less representative as an indicator of actual airborne inhalation exposure. Additional limitations of actively measuring endotoxin in air include the availability of equipment and the high costs. In addition, the noise of sampling pumps and the use of space by the equipment can be burdensome in classrooms. A previous validation study showed a good correlation between endotoxin measurements from settled dust collected on the EDC and both actively sampled PM10 airborne particles and floor dust (Noss et al., 2008).

Endotoxin levels in settled dust in schools varied strongly among the three countries, being consistent with already observed differences in home endotoxin levels in mattress dust sampled in different European countries (Chen et al., 2012; Giovannangelo et al., 2007). Differences in endotoxin levels among countries may be influenced by several factors. First, the climate differed considerably between the three countries. The average outdoor temperature during all three 8-week sampling periods was considerably lower in Finland as compared to Spain and the Netherlands. In addition, Finland is completely snow-covered during winter. Also, indoor relative humidity was lower in Finland. Low outdoor temperatures and snow cover may have reduced the influx of outdoor bacteria into schools. Together with the much drier air indoors, this might explain the considerably lower endotoxin levels in Finnish schools.

Second, cultural differences and differences in cleaning habits could also have influenced the endotoxin load in the three countries. For instance, Finnish children generally take off their shoes when entering school, which is not the common practice in the Netherlands or in Spain. The expected result would be a lower extent of tracked-in soil and associated endotoxin by shoes in Finland. In addition, all Finnish schools had mechanical ventilation, which may reduce the penetration of dust particles from outdoor air into the classroom as compared to natural ventilation. However, with this study design, we could not explore the effect of ventilation type on endotoxin levels in detail. 
We found large differences in winter and spring endotoxin levels in Finland compared with Spain and the Netherlands. This outcome could be a result of the climatic differences, with average daytime temperatures below zero during winter and with mild summers in Scandinavian countries. Park et al. (2000) observed a seasonal pattern in kitchen dust and airborne endotoxin levels of 20 Boston homes, and an even larger variation in outdoor airborne endotoxin levels, perhaps because of the shorter sampling time compared with our study. Other studies have found, however, small seasonal effects, like we found in the Netherlands and Spain, and have concluded that domestic endotoxin levels were relatively stable (Abraham et al., 2005; Heinrich et al., 2003; Simpson and Martinez, 2010). Although levels in our study varied between seasons, the intraclass correlation was high after adjustment for season, meaning that a single observation may be a good proxy for the annual endotoxin level in classrooms.

Endotoxin levels also differed within schools. In homes, endotoxin has been associated with dampness, pet ownership, farm animal contact, environmental tobacco smoke exposure, family size, and social economic status (Park et al., 2001; Thorne et al., 2009). It is likely that in schools, other factors may affect endotoxin levels as the user function differs from homes. No pets were present in the studied schools. In this study, rooms with high occupancy, such as full-time classrooms, generally had elevated endotoxin levels. The regression models also suggest a possible association between occupancy and endotoxin. This finding may indicate that bacteria or endotoxin may have been brought in by occupants, that occupants shed epithelial cells, or that other sources associated with the occupants influence the bacterial load and endotoxin levels, as previously found in studies in homes. Endotoxin levels were also high in wet areas, such as showers and bathrooms. In addition, hallways and gyms had high endotoxin levels. High activity of children in the classrooms, hallways, and gyms probably affects resuspension of settled floor dust into the air, increasing levels determined by the EDCs. Also, the grade of the classroom was inversely associated with endotoxin levels, which may be explained by the difference in physical activity or classroom characteristics (e.g., number of stuffed toys, drawings on the wall) for different age groups. As we only had limited information of these characteristics, we could not study these factors in detail in our analysis. We are not aware of other studies that explored the effect of grade on microbial levels in classrooms. A study in 64 schools in Germany found increased concentrations of particulate matter in classrooms with younger children. However, as not more than two classrooms per schools were sampled, part of the difference might also be explained by different characteristics between schools (Fromme et al., 2007).

The use of different building materials, differences in school building age, or different ventilation types might explain the variability in endotoxin levels, but our analyses did not clearly show this. Although this was a very large study, it was designed to investigate the effects of moisture in schools. Therefore, some other school determinants were very country specific (e.g., systematically different flooring materials, such as tiles only in Spain and linoleum in Finland), and it was not always possible to explore this factor fully. Another limitation is that some of our analyses, mainly on building characteristics and cleaning policy, are based on 
information obtained at the school level and sets of determinants may characterize one specific school building. However, it should be noted that this is also an issue in most other observational studies, as factors such as cleaning and the use of materials typically are uniform across classrooms within schools and do not differ per classroom. Sometimes exposure measurements are influenced by change of behavior owing to awareness of the measurements. It is not likely that occupants changed their physical behavior pattern during the 8-week sampling period. Also, cleaning behavior probably did not change over time as classrooms were cleaned daily by external staff.

Because an aim of this study was to investigate Indoor Air Quality in schools in relation to dampness, the results cannot be easily generalized to the larger general school population. In addition, only 6-11 schools per country were sampled. On the other hand, only in the Netherlands was moisture directly related to endotoxin levels. Other sources may be more relevant and the findings did not necessarily reflect endotoxin levels in schools that were specifically affected by dampness. In addition, although per country no more than 11 schools were included, this study is the largest available to date and the extensive number of measurements taken per school resulted in a methodologically strong study for assessing endotoxin levels in settled airborne dust in schools with highly relevant results.

Moisture, the independent variable of primary interest in the HITEA study, explained little endotoxin variability between schools. Dampness problems explained differences in endotoxin levels only in the Netherlands. This finding corroborates earlier observations that, unlike Spain and Finland, in the Netherlands, moisture problems were frequently observed in the classrooms (Haverinen-Shaughnessy et al., 2012). Also, among the three countries studied, long-term annual precipitation averages were highest in the Netherlands (World Weather Information Service). This might indicate that dampness problems are more difficult to control in the Netherlands compared with Spain and Finland. In addition, not all studies found evidence for a relationship between observed dampness, mold, and endotoxin in house dust (Simpson and Martinez, 2010; Solomon et al., 2006; Thorne et al., 2009).

We explored variability in endotoxin for the different cluster strategies to assess whether exposure estimations should be based on classroom measurements or based on school averages. Our results indicate that future studies in which exposure needs to be associated with health outcomes, differences in endotoxin levels between schools are the driving force. The use of classroom average endotoxin levels gives only slightly better estimates. However, adjusting for sampling period (season) improved the reproducibility $(\rho>0.50)$, especially in Finland (from $\rho=0.07$ to 0.52 ). This improvement in intraclass correlation suggests that a single observation is a reasonable estimate for annual endotoxin levels, as long as all measurements are taken at all locations simultaneously.

From a public health perspective, it is important to increase the insight in the microbial flora in schools. Despite the fact that children spend a large part of their time at school and are susceptible for exposure to indoor pollutants, the state of knowledge is limited regarding Indoor Air Quality in schools. Endotoxin in schools 
can be a potential public health concern as levels can be higher compared with homes and there are indications that asthma symptoms are higher in schools with higher endotoxin levels (Jacobs et al., 2013; Sheehan et al., 2012). Whether and how these endotoxin levels in schools can affect respiratory health will be studied in a separate part of the HITEA study. Previous research has shown that while high endotoxin levels can provoke asthma (Rabinovitch et al., 2005; Rennie et al., 2008), endotoxin might also have protective effects on the development of allergies (BraunFahrlander et al., 2002; Douwes et al., 2004; Gehring et al., 2002). With regard to teachers and pupils that are already asthmatic, it is recommended to control the levels of dust in schools. Measures that may be helpful to lower dust levels in order to decrease endotoxin and other microbial exposure include the use of entrance mats to reduce tracked-in soil, decreasing the number of occupants per room, and minimizing dust-collecting areas (such as open shelves). Also proper cleaning and maintenance of school building and the heating, ventilation, and air conditioning system are important in dust control (Health Council of the Netherlands, 2010).

In conclusion, endotoxin levels in our study are high and mainly influenced by country-specific differences, but levels between schools within the different countries are also significantly different, especially between different sampling periods. A single measurement may be a sufficient proxy for the annual average endotoxin level as the correlation between the repeated measurements is reasonable. Determinants of endotoxin levels differed per country. In general, endotoxin levels were higher in lower grades and in classrooms with higher occupancy. Effects of these determinants on endotoxin levels are generally modest and can only be identified sufficiently in large surveys with repeated measurements, like the HITEA project.

\section{ACKNOWLEDGEMENTS}

This work was supported by the European Commission as part of HITEA (Health Effects of Indoor Pollutants: Integrating microbial, toxicological and epidemiological approaches), Grant agreement no. 211488 under the Seventh Framework Programme, Topic ENV.2007.1.2.1.1. 'Indoor air pollution in Europe: An emerging environmental health issue'.

\section{REFERENCES}

Abraham, J.H., Gold, D.R., Dockery, D.W., Ryan, L., Park, J.H. and Milton, D.K. (2005) Within-home versus between-home variability of house dust endotoxin in a birth cohort, Environ. Health Perspect., 113, 1516-1521.

Borràs-Santos, A., Jacobs, J.H., Taubel, M., Haverinen-Shaughnessy, U., Krop, E.J.M., Huttunen, K., Pekkanen, J., Heederik, D., Zock, J. and Hyvärinen, A. (2013) Dampness and mould in primary schools and respiratory symptoms in children: the European HITEA study, Occup. Environ. Med., doi:10.1136/oemed-2012-101286. [Epub ahead of print].

Braun-Fahrlander, C., Riedler, J., Herz, U., Eder, W., Waser, M., Grize, L., Maisch, S., Carr, D., Gerlach, F., Bufe, A., Lauener, R.P., Schierl, R., Renz, H., Nowak, D., von Mutius, E. and Allergy and Endotoxin Study Team. (2002) Environmental exposure to endotoxin and its relation to asthma in school-age children, N. Engl. J. Med., 347, 869-877.

Chen, C.M., Thiering, E., Doekes, G., Zock, J.P., Bakolis, I., Norback, D., Sunyer, J., Villani, S., Verlato, G., Taubel, M., Jarvis, D. and Heinrich, J. (2012) Geographical variation and 
Jacobs, J.H., Krop, E.J.M., Borras-Santos, A., Zock, J.P., Täubel, M., Hyvärinen, A., Pekkanen, J., Doekes, G., Heederik, D.J.J. Endotoxin levels in settled airborne dust in European schools: the HITEA school study. Indoor Air: 2014, 24(2), 148-157

the determinants of domestic endotoxin levels in mattress dust in Europe, Indoor Air, 22, 24-32.

Douwes, J., Le Gros, G., Gibson, P. and Pearce, N. (2004) Can bacterial endotoxin exposure reverse atopy and atopic disease? J. Allergy Clin. Immunol., 114, 1051-1054.

Foarde, K. and Berry, M. (2004) Comparison of biocontaminant levels associated with hard vs. carpet floors in nonproblem schools: results of a year long study, J. Expo. Anal. Environ. Epidemiol., 14(Suppl 1), S41-S48.

Frankel, M., Timm, M., Hansen, E.W. and Madsen, A.M. (2012) Comparison of sampling methods for the assessment of indoor microbial exposure, Indoor Air, 22, 405-414.

Fromme, H., Twardella, D., Dietrich, S., Heitmann, D., Schierl, R., Liebl, B. and Rüden, H. (2007) Particulate matter in the indoor air of classrooms-exploratory results from Munich and surrounding area, Atmos. Environ., 41, 854-866.

Fromme, H., Heitmann, D., Dietrich, S., Schierl, R., Korner, W., Kiranoglu, M., Zapf, A. and Twardella, D. (2008) Air quality in schools - classroom levels of carbon dioxide (CO2), volatile organic compounds (VOC), aldehydes, endotoxins and cat allergen, Gesundheitswesen, 70, 88-97.

Gehring, U., Bischof, W., Fahlbusch, B., Wichmann, H.E. and Heinrich, J. (2002) House dust endotoxin and allergic sensitization in children, Am. J. Respir. Crit. Care Med., 166, 939944.

Gehring, U., Strikwold, M., Schram-Bijkerk, D., Weinmayr, G., Genuneit, J., Nagel, G., Wickens, K., Siebers, R., Crane, J., Doekes, G., Di Domenicantonio, R., Nilsson, L., Priftanji, A., Sandin, A., El-Sharif, N., Strachan, D., van Hage, M., von Mutius, E., Brunekreef, B. and ISAAC Phase Two Study Group. (2008) Asthma and allergic symptoms in relation to house dust endotoxin: Phase Two of the International Study on Asthma and Allergies in Childhood (ISAAC II), Clin. Exp. Allergy, 38, 1911-1920.

Giovannangelo, M., Gehring, U., Nordling, E., Oldenwening, M., Terpstra, G., Bellander, T., Hoek, G., Heinrich, J. and Brunekreef, B. (2007) Determinants of house dust endotoxin in three European countries - the AIRALLERG study, Indoor Air, 17, 70-79.

Haverinen-Shaughnessy, U., Hyvarinen, A., Pekkanen, J., Nevalainen, A., Husman, T., Korppi, M., Halla-aho, J., Koivisto, J. and Moschandreas, D. (2005) Occurrence and characteristics of moisture damage in residential buildings as a function of occupant and engineer observations, Indoor Built Environ., 14, 133-140.

Haverinen-Shaughnessy, U., Borras-Santos, A., Turunen, M., Zock, J.P., Jacobs, J., Krop, E.J., Casas, L., Shaughnessy, R., Taubel, M., Heederik, D., Hyvarinen, A., Pekkanen, J. and Nevalainen, A. (2012) Occurrence of moisture problems in schools in three countries from different climatic regions of Europe based on questionnaires and building inspections - the HITEA study, Indoor Air, 22, 457-466.

Health Council of the Netherlands. (2010) Indoor Air Quality in Primary Schools, The Hague, Health Council of the Netherlands. publication no. 2010/06E.

Heinrich, J., Holscher, B., Douwes, J., Richter, K., Koch, A., Bischof, W., Fahlbusch, B., Kinne, R.W., Wichmann, H.E. and INGA Study Group. (2003) Reproducibility of allergen, endotoxin and fungi measurements in the indoor environment, J. Expo. Anal. Environ. Epidemiol., 13, 152-160.

Jacobs, J.H., Krop, E.J.M., Spithoven, J.J., de Wind, S. and Heederik, D. (2013) Endotoxin levels in homes and classrooms of Dutch school children and respiratory health, Eur. Respir. J., 42, 314-322.

Madsen, A.M., Matthiesen, C.B., Frederiksen, M.W., Frederiksen, M., Frankel, M., Spilak, M., Gunnarsen, L. and Timm, M. (2012) Sampling, extraction and measurement of bacteria, endotoxin, fungi and inflammatory potential of settling indoor dust, J. Environ. Monit., 14, 3230-3239.

Noss, I., Wouters, I.M., Visser, M., Heederik, D.J., Thorne, P.S., Brunekreef, B. and Doekes, G. (2008) Evaluation of a low-cost electrostatic dust fall collector for indoor air endotoxin exposure assessment, Appl. Environ. Microbiol., 74, 5621-5627.

Noss, I., Doekes, G., Sander, I., Heederik, D.J., Thorne, P.S. and Wouters, I.M. (2010) Passive airborne dust sampling with the electrostatic dustfall collector: optimization of storage and extraction procedures for endotoxin and glucan measurement, Ann. Occup. Hyg., 54, 651-658. 
Park, J.H., Spiegelman, D.L., Burge, H.A., Gold, D.R., Chew, G.L. and Milton, D.K. (2000) Longitudinal study of dust and airborne endotoxin in the home, Environ. Health Perspect., 108, 1023-1028.

Park, J.H., Spiegelman, D.L., Gold, D.R., Burge, H.A. and Milton, D.K. (2001) Predictors of airborne endotoxin in the home, Environ. Health Perspect., 109, 859-864.

Rabinovitch, N., Liu, A.H., Zhang, L., Rodes, C.E., Foarde, K., Dutton, S.J., Murphy, J.R. and Gelfand, E.W. (2005) Importance of the personal endotoxin cloud in school-age children with asthma, J. Allergy Clin. Immunol., 116, 1053-1057.

Rennie, D.C., Lawson, J.A., Kirychuk, S.P., Paterson, C., Willson, P.J., Senthilselvan, A. and Cockcroft, D.W. (2008) Assessment of endotoxin levels in the home and current asthma and wheeze in school-age children, Indoor Air, 18, 447-453.

Rullo, V.E.V., Rizzo, M.C., Arruda, L.K., Solé, D. and Naspitz, C.K. (2002) Daycare centers and schools as sources of exposure to mites, cockroach, and endotoxin in the city of São Paulo, Brazil, J. Allergy Clin. Immunol., 110, 582-588.

Samadi, S., Heederik, D.J., Krop, E.J., Jamshidifard, A.R., Willemse, T. and Wouters, I.M. (2010) Allergen and endotoxin exposure in a companion animal hospital, Occup. Environ. Med., 67, 486-492.

Sheehan, W.J., Hoffman, E.B., Fu, C., Baxi, S.N., Bailey, A., King, E., Chapman, M.D., Lane, J.P., Gaffin, J.M., Permaul, P., Gold, D.R. and Phipatanakul, W. (2012) Endotoxin exposure in inner-city schools and homes of children with asthma, Ann. Allergy Asthma Immunol., 108, 418-422.

Simpson, A. and Martinez, F.D. (2010) The role of lipopolysaccharide in the development of atopy in humans, Clin. Exp. Allergy, 40, 209-223.

Solomon, G.M., Hjelmroos-Koski, M., Rotkin-Ellman, M. and Hammond, S.K. (2006) Airborne mold and endotoxin concentrations in New Orleans, Louisiana, after flooding, October through November 2005, Environ. Health Perspect., 114, 1381-1386.

Thorne, P.S., Cohn, R.D., Mav, D., Arbes, S.J. and Zeldin, D.C. (2009) Predictors of endotoxin levels in U.S. housing, Environ. Health Perspect., 117, 763-771.

Tischer, C., Gehring, U., Chen, C.M., Kerkhof, M., Koppelman, G., Sausenthaler, S., Herbarth, O., Schaaf, B., Lehmann, I., Kramer, U., Berdel, D., von Berg, A., Bauer, C.P., Koletzko, S., Wichmann, H.E., Brunekreef, B. and Heinrich, J. (2011) Respiratory health in children, and indoor exposure to $(1,3)$-beta-D-glucan, EPS mould components and endotoxin, Eur. Respir. J., 37, 1050-1059.

World Health Organization. (2009) WHO guidelines for indoor air quality: dampness and mould, World Weather Information Service (Annual averages for the period 1971-2000).

Zhao, Z., Sebastian, A., Larsson, L., Wang, Z., Zhang, Z. and Norback, D. (2008) Asthmatic symptoms among pupils in relation to microbial dust exposure in schools in Taiyuan, China, Pediatr. Allergy Immunol., 19, 455-465. 
Jacobs, J.H., Krop, E.J.M., Borras-Santos, A., Zock, J.P., Täubel, M., Hyvärinen, A., Pekkanen, J., Doekes, G., Heederik, D.J.J. Endotoxin levels in settled airborne dust in European schools:

the HITEA school study. Indoor Air: 2014, 24(2), 148-157

\section{FIGURES AND TABLES}

Table 1 School characteristics and endotoxin levels measured with the electrostatic dust fall collectors (EDCs) in Spanish, Dutch and Finnish schools

\begin{tabular}{|c|c|c|c|c|c|c|c|c|c|}
\hline \multirow{3}{*}{$\begin{array}{l}\text { Number of schools } \\
\text { (index/reference) }\end{array}$} & \multicolumn{3}{|l|}{ Spain } & \multicolumn{3}{|l|}{ The Netherlands } & \multicolumn{3}{|l|}{ Finland } \\
\hline & \multicolumn{3}{|l|}{$7(5 / 2)$} & \multicolumn{3}{|l|}{$10(5 / 5)$} & \multicolumn{3}{|l|}{$6(4 / 2)$} \\
\hline & EA1 (2009) & EA2 (2009) & EA3 (2010) & EA1 (2009) & EA2 (2009) & EA3 (2010) & EA1 (2009) & EA2 (2009) & EA3 (2010) \\
\hline $\begin{array}{l}\text { Measuring period } \\
\text { (start/end date) }^{\mathrm{a}}\end{array}$ & $\begin{array}{l}\text { Jan 30th } \\
\text {-April 15th }\end{array}$ & $\begin{array}{l}\text { April 15th } \\
\text {-June 30th }\end{array}$ & $\begin{array}{l}\text { Jan 12th } \\
\text {-March 22nd }\end{array}$ & $\begin{array}{l}\text { Feb 23rd } \\
\text {-April 22nd }\end{array}$ & $\begin{array}{l}\text { May } 11 \text { th } \\
\text {-July } 7 \text { th }\end{array}$ & $\begin{array}{l}\text { March 1st } \\
\text {-April 27th }\end{array}$ & $\begin{array}{l}\text { Jan 26th } \\
\text {-March 30th }\end{array}$ & $\begin{array}{l}\text { March 23rd } \\
\text {-May 25th }\end{array}$ & $\begin{array}{l}\text { Feb 1st } \\
\text {-March 31st }\end{array}$ \\
\hline \multicolumn{10}{|c|}{ Outdoor climate (8-week average) } \\
\hline $\begin{array}{l}\text { Temperature }{ }^{\circ} \mathrm{C}- \\
\text { mean (s.d.) }\end{array}$ & $10.1(0.66)$ & $19.7(1.32)$ & $7.5(0.18)$ & $6.2(-)^{c}$ & $15.9(-)^{c}$ & $9.2(-)^{c}$ & $-5.9(0.11)$ & $4.2(0.87)$ & $-8.6(0.28)$ \\
\hline $\begin{array}{c}\text { Precipitation } \\
\text { mm - mean } \\
\text { /day (s.d.) } \\
\text { Indoor climate }\end{array}$ & $1.3(0.62)$ & $0.6(0.27)$ & $3.1(0.10)$ & $1.1(-)^{c}$ & $2.0(-)^{c}$ & $0.5(-)^{c}$ & $0.6(0.07)$ & $1.3(0.06)$ & $1.4(0.10)$ \\
\hline $\begin{array}{l}\text { Temperature }{ }^{\circ} \mathrm{C}- \\
\text { mean (s.d.) }\end{array}$ & $22(1.7)$ & & $23(1.7)$ & $21(1.7)$ & & $21(1.6)$ & $22(1.1)$ & & $22(1.15)$ \\
\hline $\begin{array}{l}\text { Relative humidity\% - } \\
\text { mean (s.d.) }\end{array}$ & $44(9.3)$ & & $41(9.4)$ & $43(7.5)$ & & $37(7.6)$ & $16(3.9)$ & & $14(6.5)$ \\
\hline $\begin{array}{l}\text { Excluded } \\
\text { samples (\%) }\end{array}$ & 5 & 10 & 15 & 5 & 6 & 3 & 4 & 4 & 6 \\
\hline $\begin{array}{l}\text { Valid sampling } \\
\text { locations }(n)\end{array}$ & 113 & 88 & 89 & 149 & 134 & 148 & 111 & 106 & 105 \\
\hline $\begin{array}{l}\text { Number of classroom } \\
\text { occupants } \\
\text {-mean (s.d.) } \\
\text { Endotoxin load } \\
\left(\mathrm{kEU} / \mathrm{m}^{2}\right)\end{array}$ & & & $24(2.1)$ & & & $24(3.7)$ & & & $21(5.6)$ \\
\hline $\begin{array}{l}\text { All schools } \\
\text { (GM, GSD) }\end{array}$ & $18.3(2.24)$ & $14.9(2.07)^{*}$ & $19.4(2.05)$ & $26.2(2.06)$ & $29.0(1.90)$ & $30.8(1.85)^{* *}$ & $1.1(2.43)$ & $3.8(2.37)^{*}$ & $1.1(2.16)$ \\
\hline $\begin{array}{l}\text { Index schools } \\
\text { (GM, GSD) }\end{array}$ & $18.8(2.17)$ & $15.2(2.15)$ & $20.5(2.12)$ & $34.1(1.95)^{* * *}$ & $39.3(1.82)^{* * *}$ & $35.8(1.95)^{* * *}$ & $1.2(2.40)$ & $4.2(2.24)$ & $1.0(2.17)$ \\
\hline $\begin{array}{l}\text { Reference schools } \\
\text { (GM, GSD) }\end{array}$ & $17.2(2.47)$ & $14.2(1.87)$ & $16.4(1.81)$ & $20.4(1.99)$ & $21.3(1.68)$ & $26.4(1.68)$ & $1.0(2.48)$ & $3.0(2.68)$ & $1.3(2.08)$ \\
\hline
\end{tabular}

GM, geometric mean; GSD, geometric standard deviation; s.d., standard deviation.

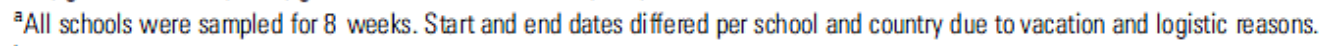

${ }^{\mathrm{b}}$ Assessed in one classroom per school over 1 week, with children aged 10-11 years in the classroom.

In the Netherlands, all 8-week measurements were taken in parallel, so the standard deviation of the outdoor temperature and amount of precipitation was 0.

${ }^{*}$ Significantly different from the measurements in period 1 (winter/spring 2009) and period 3 (winter/spring 2010; $P \leq 0.05$ ).

${ }^{* *}$ Significantly different from the measurements in period 1 (winter/spring 2009) and period 2 (spring 2010; $P \leq 0.05$ ).

***Significantly different from reference schools $(P \leq 0.05)$. 


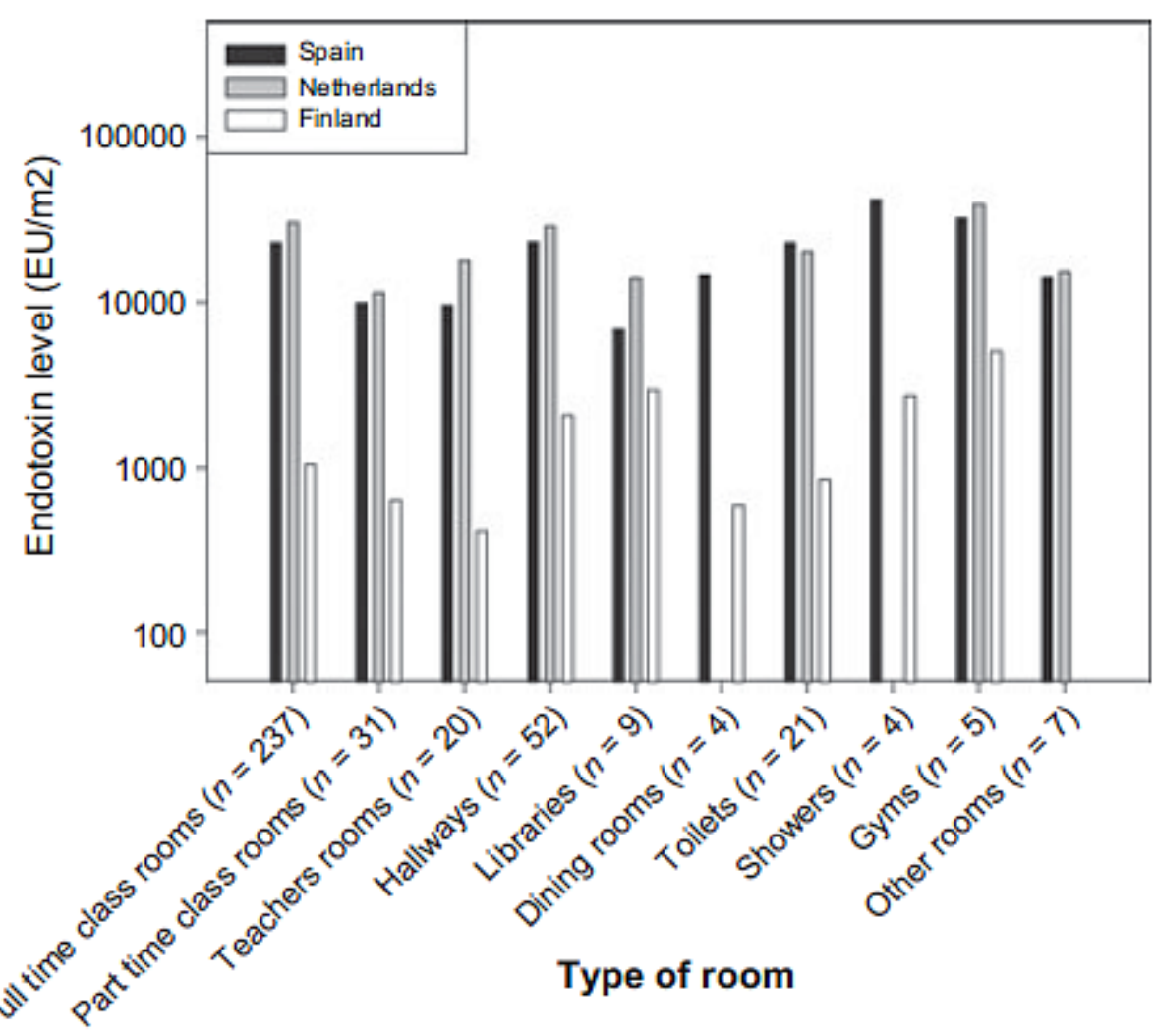

Fig. 1 Average (geometric mean) endotoxin levels in different type of rooms in schools across three countries 
Jacobs, J.H., Krop, E.J.M., Borras-Santos, A., Zock, J.P., Täubel, M., Hyvärinen, A., Pekkanen, J., Doekes, G., Heederik, D.J.J. Endotoxin levels in settled airborne dust in European schools: the HITEA school study. Indoor Air: 2014, 24(2), 148-157

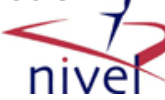

Table 2 Variance components estimates of the randomeffects model for log-transformed endotoxin levels (EU/ $\left.\mathrm{m}^{2}\right)$ in classrooms of primary schools

\begin{tabular}{|c|c|c|c|c|c|c|c|}
\hline \multirow[b]{2}{*}{ Country } & \multirow[b]{2}{*}{$k$} & \multirow[b]{2}{*}{$n$} & \multirow[b]{2}{*}{$N$} & \multirow[b]{2}{*}{ Cluster level } & \multicolumn{3}{|c|}{ Unconditional random-effects model } \\
\hline & & & & & Variance component estimate & GSD & $\%$ Variance of total variance \\
\hline \multirow[t]{7}{*}{ Overall } & \multirow[t]{7}{*}{23} & \multirow[t]{7}{*}{237} & \multirow[t]{7}{*}{645} & Country & 0.491 & 2.01 & 83 \\
\hline & & & & Moisture category & 0.002 & 1.05 & 0 \\
\hline & & & & School & 0.022 & 1.16 & 4 \\
\hline & & & & Buildings & 0.005 & 1.07 & 1 \\
\hline & & & & Zone & 0.005 & 1.08 & 1 \\
\hline & & & & Classrooms & 0.000 & 1.00 & 0 \\
\hline & & & & $\begin{array}{l}\text { Between sampling periods } \\
\text { (within a classroom) }\end{array}$ & 0.069 & 1.30 & 12 \\
\hline \multirow[t]{6}{*}{ Spain } & \multirow[t]{6}{*}{7} & \multirow[t]{6}{*}{64} & \multirow[t]{6}{*}{164} & Moisture category & 0.000 & 1.00 & 0 \\
\hline & & & & School & 0.032 & 1.20 & 43 \\
\hline & & & & Buildings & 0.000 & 1.00 & 0 \\
\hline & & & & Zone & 0.000 & 1.01 & 0 \\
\hline & & & & Classrooms & 0.004 & 1.07 & 6 \\
\hline & & & & $\begin{array}{l}\text { Between sampling periods } \\
\text { (within a classroom) }\end{array}$ & 0.037 & 1.21 & 51 \\
\hline \multirow[t]{6}{*}{ Netherlands } & \multirow[t]{6}{*}{10} & \multirow[t]{6}{*}{102} & \multirow[t]{6}{*}{280} & Moisture category & 0.009 & 1.10 & 13 \\
\hline & & & & School & 0.018 & 1.14 & 26 \\
\hline & & & & Buildings & 0.007 & 1.09 & 11 \\
\hline & & & & Zone & 0.000 & 1.00 & 0 \\
\hline & & & & Classrooms & 0.000 & 1.00 & 0 \\
\hline & & & & $\begin{array}{l}\text { Between sampling periods } \\
\text { (within a classroom) }\end{array}$ & 0.035 & 1.20 & 51 \\
\hline \multirow[t]{6}{*}{ Finland } & \multirow[t]{6}{*}{6} & \multirow[t]{6}{*}{71} & \multirow[t]{6}{*}{201} & Moisture category & 0.000 & 1.01 & 0 \\
\hline & & & & School & 0.012 & 1.12 & 7 \\
\hline & & & & Buildings & 0.009 & 1.10 & 6 \\
\hline & & & & Zone & 0.002 & 1.05 & 1 \\
\hline & & & & Classrooms & 0.000 & 1.00 & 0 \\
\hline & & & & $\begin{array}{l}\text { Between sampling periods } \\
\text { (within a classroom) }\end{array}$ & 0.139 & 1.45 & 86 \\
\hline
\end{tabular}

$k$, number of schools visited; $n$, number of classrooms sampled; $N$, total number of samples included. 
Jacobs, J.H., Krop, E.J.M., Borras-Santos, A., Zock, J.P., Täubel, M., Hyvärinen, A., Pekkanen, J., Doekes, G., Heederik, D.J.J. Endotoxin levels in settled airborne dust in European schools: the HITEA school study. Indoor Air: 2014, 24(2), 148-157

Table 3 The variance components, variance ratio $(\lambda=$ ratio within/between variance) and intraclass correlation $(\rho)$ of endotoxin levels for different grouping approaches in three countries across Europe

\begin{tabular}{|c|c|c|c|c|c|c|}
\hline \multirow[b]{3}{*}{ Cluster level } & \multicolumn{6}{|c|}{ Random-effects model } \\
\hline & \multicolumn{2}{|c|}{$\begin{array}{l}\text { Variance } \\
\text { component } \\
\text { estimate }\end{array}$} & \multicolumn{2}{|l|}{ GSD } & \multirow[b]{2}{*}{$\lambda$} & \multirow[b]{2}{*}{$\rho$} \\
\hline & Between & Within & Between & Within & & \\
\hline \multicolumn{7}{|l|}{ Spain } \\
\hline Moisture & 0.000 & 0.043 & 1.01 & 1.31 & 987 & 0 \\
\hline School & 0.035 & 0.041 & 1.21 & 1.23 & 1.18 & 0.46 \\
\hline Building (within school) & 0.041 & 0.042 & 1.23 & 1.23 & 1.01 & 0.50 \\
\hline Zone (within school) & 0.034 & 0.040 & 1.20 & 1.22 & 1.16 & 0.46 \\
\hline Classroom (within school) & 0.036 & 0.038 & 1.21 & 1.22 & 1.06 & 0.49 \\
\hline \multicolumn{7}{|l|}{ Netherlands } \\
\hline Moisture & 0.013 & 0.055 & 1.12 & 1.26 & 4.21 & 0.19 \\
\hline School & 0.027 & 0.037 & 1.18 & 1.21 & 1.37 & 0.42 \\
\hline Building (within school) & 0.026 & 0.035 & 1.17 & 1.20 & 1.34 & 0.43 \\
\hline Zone (within school) & 0.026 & 0.033 & 1.18 & 1.20 & 1.25 & 0.45 \\
\hline Classroom (within school) & 0.038 & 0.024 & 1.21 & 1.17 & 0.62 & 0.62 \\
\hline \multicolumn{7}{|l|}{ Finland } \\
\hline Moisture & 0.005 & 0.155 & 1.07 & 1.48 & 30 & 0.03 \\
\hline School & 0.016 & 0.144 & 1.13 & 1.46 & 9.17 & 0.10 \\
\hline Building (within school) & 0.019 & 0.140 & 1.15 & 1.45 & 7.38 & 0.12 \\
\hline Zone (within school) & 0.023 & 0.135 & 1.17 & 1.44 & 5.79 & 0.15 \\
\hline Classroom (within school) & 0.011 & 0.146 & 1.11 & 1.47 & 13 & 0.07 \\
\hline
\end{tabular}

2: Variance ratio: Ratio of within-group vs. between-group variance.

$\rho$ : Intraclass correlation: Ratio of between-group vs. sum of between- and within-group variance; representing reproducibility of repeated measurements within groups. 
Jacobs, J.H., Krop, E.J.M., Borras-Santos, A., Zock, J.P., Täubel, M., Hyvärinen, A., Pekkanen, J., Doekes, G., Heederik, D.J.J. Endotoxin levels in settled airborne dust in European schools: the HITEA school study. Indoor Air: 2014, 24(2), 148-157

Table 4 Covariates potentially affecting endotoxin levels (univariate analyses)

\begin{tabular}{|c|c|c|c|}
\hline Covariate & $\begin{array}{l}\text { Spain } \\
\text { GM ratio (95\% Cl) }\end{array}$ & $\begin{array}{l}\text { Netherlands } \\
\text { GM ratio (95\% Cl) }\end{array}$ & $\begin{array}{l}\text { Finland } \\
\text { GM ratio (95\% Cl) }\end{array}$ \\
\hline \multicolumn{4}{|c|}{ Specific measurement information (location specific) } \\
\hline \multicolumn{4}{|l|}{ Sampling period } \\
\hline 1 & 1.00 (ref) & 1.00 (ref) & 1.00 (ref) \\
\hline 2 & $090(0.84-0.97)$ & $1.02(0.98-1.07)$ & $1.76(1.64-1.89)$ \\
\hline 3 & $0.99(0.93-1.07)$ & $1.08(1.04-1.13)$ & $1.02(0.95-1.09)$ \\
\hline \multicolumn{4}{|l|}{ Moisture status school } \\
\hline Index vs. reference & $1.03(0.88-1.19)$ & $1.19(0.98-1.44)$ & $1.13(0.89-1.44)$ \\
\hline \multicolumn{4}{|l|}{ Grade } \\
\hline Two grades increase & $0.97(0.94-1.01)$ & $0.97(0.95-1.00)$ & $0.92(0.87-0.98)$ \\
\hline \multicolumn{4}{|l|}{ Occupancy } \\
\hline Five people increase & $1.04(0.90-1.20)$ & $1.04(0.99-1.10)$ & $1.13(1.08-1.19)$ \\
\hline \multicolumn{4}{|c|}{ Information on cleaning (on school building level) } \\
\hline \multicolumn{4}{|c|}{ Hours cleaning } \\
\hline $5 \mathrm{~h}$ increase & $0.99(0.96-1.03)$ & $0.96(0.83-1.12)$ & $0.90(0.72-1.13)$ \\
\hline \multicolumn{4}{|l|}{ Frequency dusting } \\
\hline Less often & $1.15(0.97-1.37)$ & $1.02(0.95-1.09)$ & $1.15(1.06-1.25)$ \\
\hline \multicolumn{4}{|l|}{ Frequency sweeping } \\
\hline Less often & $a$ & $1.05(1.01-1.09)$ & $0.91(0.87-0.95)$ \\
\hline \multicolumn{4}{|c|}{ Information from building inspections (on school building level) } \\
\hline \multicolumn{4}{|c|}{ Building year } \\
\hline+10 years & $0.95(0.85-1.05)$ & $0.97(0.94-1.00)$ & $0.93(0.87-1.00)$ \\
\hline \multicolumn{4}{|l|}{ Floor material used } \\
\hline Linoleum/PVC & a & 1.00 (ref) & 1.00 (ref) \\
\hline Carpet & $a$ & $0.96(0.67-1.39)$ & a \\
\hline \multicolumn{4}{|l|}{ Stuffed toys in classroom } \\
\hline Yes & $0.89(0.57-1.39)$ & $1.17(1.08-1.27)$ & $1.00(0.77-1.32)$ \\
\hline \multicolumn{4}{|c|}{ Type of ventilation present } \\
\hline Mochanical exhaust & $1.01(0.71-1.44)$ & $1.03(0.88-1.21)$ & $a$ \\
\hline $\begin{array}{l}\text { Mechanical support } \\
\text { of outdoor air }\end{array}$ & $0.99(0.70-1.41)$ & $0.96(0.82-1.14)$ & $a$ \\
\hline \multicolumn{4}{|l|}{ Signs of moisture damage } \\
\hline Yes & $1.04(0.73-1.48)$ & $1.18(1.04-1.35)$ & $1.14(0.88-1.48)$ \\
\hline \multicolumn{4}{|l|}{ Signs of visible mold } \\
\hline Yes & $0.78(0.52-1.17)$ & $1.18(1.04-1.35)$ & $0.88(0.63-1.23)$ \\
\hline \multicolumn{4}{|c|}{ Major water intrusion past 5 years } \\
\hline Yes & $1.09(0.80-1.50)$ & $1.16(1.06-1.27)$ & $1.09(0.84-1.43)$ \\
\hline \multicolumn{4}{|l|}{ Complaints on damoness } \\
\hline Yes & $0.78(0.52-1.17)$ & $1.18(1.04-1.35)$ & $0.90(0.7-1.15)$ \\
\hline \multicolumn{4}{|l|}{ Complaints on lAQ } \\
\hline Yes & $0.90(0.54-1.49)$ & $0.98(0.89-1.08)$ & $1.15(0.91-1.45)$ \\
\hline \multicolumn{4}{|c|}{ Information on indoor classroom climate (during school hours) } \\
\hline \multicolumn{4}{|l|}{ Ventilation (median $\mathrm{CO}_{2}$ ) } \\
\hline $\begin{array}{r}\text { Per } 100 \mathrm{ppm}+ \\
\text { Temperature }\left({ }^{\circ} \mathrm{C}\right)\end{array}$ & $1.01(0.99-1.02)$ & $0.98(0.96-1.00)$ & $0.93(0.89-0.98)$ \\
\hline Per $1^{\circ} \mathrm{C}+$ & $1.05(1.01-1.09)$ & $0.99(0.96-1.03)$ & $1.08(0.99-1.18)$ \\
\hline Relative humidity (\%) & & & \\
\hline Per $10 \%+$ & $1.27(1.14-1.42)$ & $0.96(0.92-1.01)$ & $0.99(0.8-1.22)$ \\
\hline
\end{tabular}

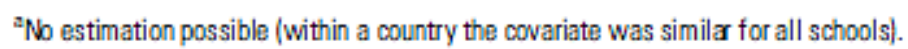

bInformation was completed by the person responsible for the cleaning or otherwise by a school representative. Frequency in cleaning was categor ized as: daily, 2-4 times a week, once a week and less than once a week and analyzed and treated $a$ a continuous variable in the model.

'Compared with only natural ventilation (windows).

Bold values indicate significance of $P \leq 0.05$. 